\title{
The Validity and Reliability of Rational Emotive Behavioural Therapy Module Development for University Support Staff
}

\author{
Nurul Iman Abdul Jalil ${ }^{1}$ \& Mastura Mahfar ${ }^{1}$ \\ ${ }^{1}$ Faculty of Management, Universiti Teknologi Malaysia, Malaysia \\ Correspondence: Nurul Iman Abdul Jalil, Faculty of Management, Universiti Teknologi Malaysia, Malaysia. \\ E-mail: nuruliman.abduljalil@gmail.com
}

Received: December 6, 2015

doi:10.5539/ass.v12n2p129
Accepted: December 15, 2015 Online Published: January 12, 2016

URL: http://dx.doi.org/10.5539/ass.v12n2p129

\begin{abstract}
This study introduces the Rational Emotive Behavioural Therapy Module for university support staff in lessening their irrational beliefs and job stress which more emphasize on cognitive aspect beside emotion and behavioural aspects. The Rational Emotive Behavioural Therapy (REBT) which introduced by Albert Ellis (1994) was employed as a guideline in developing the module. The process of module's development content was compiled based on the four sub modules, namely Self-acceptance, Feelings, Beliefs and Disputation which adapted from previous REBT practitioners and researchers. After the module developed, the analysis of validity and reliability were tested. The content validity of the module was evaluated by five experts and the result indicated that the value of validity coefficient is high which is .91 . Meanwhile, the reliability analysis was tested by employing a questionnaire based on the steps of module's activity. The result showed that the value of reliability coefficient is also high which is .98. In conclusion, the study demonstrates that the REBT Module has a high validity and reliability which can be utilized by support staff at university.
\end{abstract}

Keywords: REBT, developing, module, validity, reliability, irrational belief, job stress

\section{Introduction}

Employees around the world have reported that they feel increasingly stressed at work (Murphy \& Sauter, 2003). Moreover, according to Nilufar Ahsan, David Yong and Syed Shah Alam (2009), there is an increasing concern about job stress in developing countries. When individual decided to sign up for a job, it has become a part of their working life as it brings a load of responsibilities, demands, problems and pressure. It occurs when employees perceive an imbalance between their work demands and their capability and resources to meet these demands (Yin-Fah, Foon, Lim, \& Syuhaily, 2010).

Even though some situations can be intrinsically stressful, Bora, Bernard, Trip, Decsei-Radu and Chereji (2009) remarked that in most situations, individuals create their own negative emotions because they tend to be judgemental and their dysfunctional reactions results from their own beliefs. Although the activating event contributes to what an individual thinks or believes, it does not cause it (Bora et al., 2010). A study by Bond and Dryden (1996) showed that irrational beliefs are related to specific automatic thoughts during stressful events.

Ellis (2006) stated that Rational Emotive Behavioural Therapy (REBT) is one of the individual-based stress management interventions and this approach assists the individual in mediating and disputing the irrational beliefs and reinforces the rational beliefs. Therefore, this paper explains how the module was developed, as well as how the testing of validity and reliability of REBT Module was performed, so that the module can be used by REBT practitioners or researchers in order to reduce the irrational beliefs and job stress among university support staff. Furthermore, job stress can be alleviated by employing the REBT as Jenkins and Palmer (2003) stated that the essential objectives of REBT approach is stress does not exist in the event but involve a set of cognitive, affective and coping variables, then focus on changing appraising and coping.

\section{Rational Emotive Behavioural Therapy}

REBT is a form of Cognitive Behaviour Therapy (CBT) and it can be defined as a theory that portrays interrelated dimensions of cognitions, emotions and behaviour which plays a major role and it influences all aspects of human life (Mukangi, 2010). The goal of REBT is to assist individuals to manage extreme emotions that may interfere with one's ability to achieve personal and professional goals (Banks \& Zionts, 2009). In 
addition, REBT helps individual to pay attention to the way they think, in order to observe the level of rationality as this will lead them to experience healthy feelings and behaviours. Through REBT, one can also identify when they are going through irrationality, so that they are able to be cautious of the time that their thoughts may lead them to destructive feelings and behaviours (Ellis, 2006).

The main component of the REBT approach is that ABC Model which is the fundamental of irrational beliefs and emotional disturbances of individuals (Ellis \& Dryden, 1997). According to Ellis and Bernard (1983), there are three main parts in the ABC Model namely events (A), the system of belief (B) as well as emotional and behavioural effects of individual (C). Most individuals assumed that their emotional and behavioural (C) are due to the events that occur (A). Otherwise, the rational or irrational beliefs (B) of an event are the cause of emotional and behavioural to individuals $(\mathrm{C})$. Thus, the emotional and behavioural disturbances of the individual are caused by the irrational beliefs held by them.

Dryden (1999) remarked that REBT does not hold the past events at ' $A$ ' lead to psychological disturbance at ' $C$ '. Rather it holds that people make themselves disturbed at ' $\mathrm{C}$ ' by bringing their tendencies to think irrationally at 'B' to events that happened in the past A. According to Jenkins and Palmer (2003) the key objectives of REBT approach is that stress does not exist in the event but encompasses a set of cognitive, affective and coping variables, then focus on changing appraising and coping.

In consequence, individual will be taught on how to think, feel, and act against rigid irrational beliefs with a number of cognitive, emotive, and behavioural techniques, which interrelate to each other. Besides that, they will be trained on how to specifically dispute their irrational beliefs by using arguments empirically, logically and pragmatically (Dryden \& Branch, 2008). Then, demonstration can be carried out to show them how to change their rigid, absolutistic demands on themselves, other people and world conditions to flexible, workable preferences. For instance, if a staff is holding an irrational belief that "I must be a good worker and perform in what I am doing", but after the staff knowing how to dispute their own irrational beliefs, he will replace this belief with the rational belief. For example, "I want to be a good worker and perform in what I am doing, however, sometimes a good worker also make mistakes".

\section{Statement of Problem}

Mohd Awang Idris, Dollard, and Winefield (2010) said that occupational stress intervention strategies are still underdeveloped in Malaysian organizations. Palmer (2002) claimed that there is little published research on the effectiveness of cognitive stress prevention techniques taught to non-clinical population. This is an area that needs further research to support the demands of many optimistic stress management practitioners.

In addition, until now researcher does not discover yet any development of module that focus on cognitive especially utilizing the REBT approach that test on validity and reliability of module in lessening the irrational beliefs and job stress among university support staff except for the research conducted by Amalia Madihie and Sidek Mohd Noah (2013) on orphans and Mastura Mahfar (2011) on students. Although, Sapora Sipon (2007) had administered an experimental research to measure the effects of Rational Emotive Behavioural treatment, her research was focused on teachers as the subjects of research.

As stated by Sidek Mohd Noah and Jamaludin Ahmad (2005), it is important to follow the steps that have been set out in the process of development of a module in order to ensure the quality of a module itself. Therefore, the first research question of this research is 'How to develop REBT Module?' and followed by the second and the third research questions which are 'How to determine the module that contain a high validity?' and 'How to determine the module that contain a high reliability?' will be answered in the study.

\section{Objectives of the Study}

The general objective of the study is to develop REBT Module on support staff that has a high validity and reliability. Hence, the specific objectives are:

(1) To develop the REBT Module for university support staff.

(2) To determine the content validity of the REBT Module for university support staff.

(3) To determine the reliability of the REBT Module for university support staff.

\section{Methodology of the Study}

This part discusses the methodology utilized in the study relating the research design, instruments, validity, reliability and data analysis. 


\subsection{REBT Module}

In this research, REBT Module was developed by referring to the Sidek's Module Development Model (Sidek Mohd Noah \& Jamaludin Ahmad, 2005). Sidek Mohd Noah (2001) introduced an integration model which is more comprehensive in developing a module. The model has been widely employed by many Malaysian reseachers, for instances Amalia Madihie and Sidek Mohd Noah (2013), Mastura Mahfar (2011), Mohd Ali Jaamat (2010) and Abdul Hanid Halit (2007) in order to determine the validity and reliability of their modules. This model comprises of two stages, each with different purposes. The first stage produced a draft module. There are nine steps. It starts off with developing an aim of the module and then identifying theories, rational, philosophy, concept target and time allocation. After that, it will be followed by needing an assessment, setting the objectives, selecting the content, strategy, logistic and media. Lastly, it ends with integrating the draft module.

Afterward, at the second stage, the module itself will be tested and evaluated. This draft module will undergo a pilot test to assess its validity, reliability and norms. If it is proven that this module is high in validity and reliability, then it can be considered as a complete module and can be proceed onto the last step; effective evaluation. After following these two stages, the module can be employed to target population (Sidek Mohd Noah, 2001). Figure 1 below illustrated the process of module development based on Sidek Mohd Noah and Jamaludin Ahmad (2005).

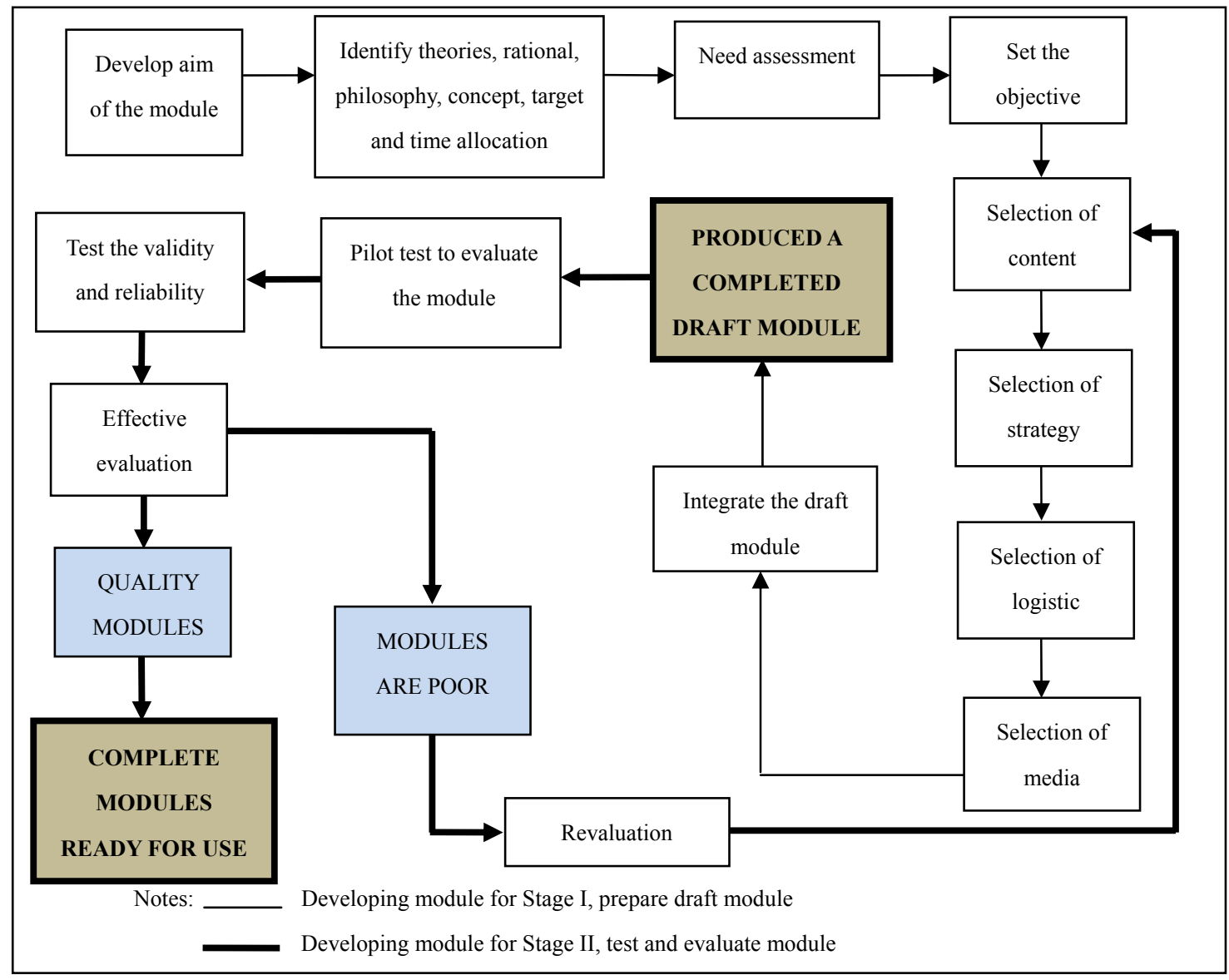

Figure 1. sidek's module development model

(Source: Noah \& Ahmad, 2005)

Then, the process of development content of this module has been compiled based on the sub module. There are four sub modules in which adapted from previous REBT scholars and researchers from local and abroad. The module is also developed according to four basic concepts put forward by Vernon (2004), namely self-acceptance, feelings, beliefs and disputation. Although the module by Vernon (2004) focused on teenagers, the basic concepts introduced are still associated with the ABC Model in the REBT approach. Each sub module 
has its objective, activities as well as steps to implement it and work sheets that need to be completed by the university support staff.

The content of the Rational Emotive Behavioural Therapy Module has been developed by combining the learning content of Rational Emotive Behavioural Therapy and Rational Emotive Behavioural Education by previous developers such as Mastura Mahfar (2011), Dryden (1999, 1998), Ellis, Gordon, Neenan and Palmer (1997), Vernon (1989) and Bernard and Joyce (1984) using the REBT approach. Bernard and Joyce (1984) and Mastura Mahfar, Amat Senin Aslan, Sidek Mohd Noah, Jamaluddin Ahmad and Wan Marzuki Wan Jaafar (2014) developed a combination of learning content from Rational Emotive Education from the previous designers and shown the effectiveness in the findings of the study.

Furthermore, there are some modifications in the content of the module that has been carried out by the researcher towards the previous content modules by Western developers in order to ensure the development of module is suitable with the background of the university support staff in Malaysian context. Moreover, there are several activities which were designed by the researcher. These activities have been designed according to the basic concepts of REBT and also included several graphic elements and interactive activities to increase interest and attention of staff to follow as well as activities such as role play, discussions, and individual and group assignments. According to Sidek Mohd Noah and Jamaludin Ahmad (2005), the concept of the module should represent the implementation of the module in the real situation for example in the form of games, exercise, talk and others. Besides that, they added that the selection of media is important in order to attract, motivate and stimulate the subject of research to follow the module.

In addition, the researcher provides short notes related to the activities in enhancing the staff's understanding towards the activities that had been designed. After the module has been developed, the analysis of validity and reliability were tested. Overall, there are 19 activities based on the description of four sub modules that take 18 hours 50 minutes.

\subsection{Validity and Reliability}

In testing the validity of the module, the researcher used content validity to measure how well the activities in each sub modules represent the REBT Module. This module was evaluated by the experts who were qualified with experience in counselling and also developing module as taking the recommendation by Majid Konting (1998) to obtain the external assessors who are experts in fields related to the area being studied. These experts assessed the suitability of the items used to measure the selected domain in the module and instruments. In order to measure it, the researcher developed a form of questionnaire based on the content validity of the module which constructed by Jamaludin Ahmad (2002).

The questionnaire contains five items using five-point of Likert Scale from 1 (strongly disagree) until 5 (strongly agree). Moreover, there are some modifications from the original questionnaire in order to adapt the needs of the research objectives. Besides that, there is a blank space in that questionnaire to enable the experts to provide feedback and recommendation regarding the proposed module.

Meanwhile, the calculation method for content validity is based on the formula that was suggested by Sidek Mohd Noah and Jamaludin Ahmad (2005) which is based from Russell Formula (1974). The total score given by each expert $(\mathrm{X})$ is divided by the total maximum score of the Likert scale (25) and then multiplied by 100 per cent. In obtaining the achievement of content validity in decimal figure, the researcher should change it to decimal figure with 100 per cent as 1.00 and 0 per cent as .00 which resembling the correlation coefficient value (Sidek Mohd Noah \& Jamaludin Ahmad, 2005). Figure 2 shows how to analyse the content validity of REBT Module.

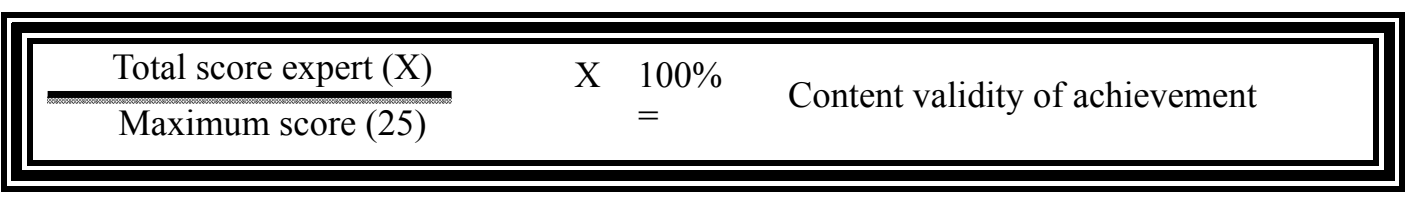

Figure 2. Formula to analyse the content validity of REBT module

Besides that, a good module should also have high reliability. Method for determining the reliability of a module is similar to the method of determining the reliability of module similar to the method for determining the reliability of the test or measurement instruments (Noah \& Ahmad, 2005). This is because both of the module and the test are developed specifically for a test. 
The evaluation of a module can be determined by observing the extent of the participants able to follow the steps in activity successfully (Russell, 1974). Therefore, the reliability of a module can be tested by employing a questionnaire based on the steps of module's activity or the objectives of the module as recommended by Sidek Mohd Noah and Jamaludin Ahmad (2005). In this study, there were 169 questionnaires that need to be answered by the sample of study based on the 19 activities for all four sub modules.

This questionnaire was distributed to the samples in the pilot test after they had completed the training on that module. Then, the questionnaires were analysed using Cronbach Alpha to obtain the reliability coefficient of the module. This method is based on the standard deviation of measurement instruments and a standard deviation of different items (Noah \& Ahmad, 2005). After that, the researcher can identify the weaknesses of the module itself in terms of the suitability of activities, time usage to finish the module and its activities, suitability the activities of module with the target sample, clarity of the objectives, steps of activities and instructions and others.

\subsection{Sample of the Study}

In order to evaluate the content validity of the REBT Module, the researcher selected five experts who possessed Doctor of Philosophy $(\mathrm{PhD})$ and are qualified with experience in psychology and counselling fields from several universities in Malaysia.

Whereas, to test the reliability of the module, a total of 27 support staff in a university in Malaysia were selected for the pilot study. The term of 'support staff' in this research referred to all non-academic and non-executive staff employed within the university sector, including in academic support, administrative support, library and technical areas. All of them are Malay staff.

\section{Findings and Discussion}

\subsection{Validity of Module}

Table 1. Analysis of validity coefficient for REBT module's content

\begin{tabular}{llcc}
\hline \multicolumn{1}{c}{ Item Statements } & $\begin{array}{c}\text { Percentage } \\
(\%)\end{array}$ & $\begin{array}{c}\text { Validity } \\
\text { Coefficient }\end{array}$ \\
\hline 1. The content of REBT Module for support staff meets the target populations. & 92 & .92 \\
2. The content of REBT Module for support staff can be implemented successfully. & 88 & .88 \\
3. The content of REBT Module for support staff is compatible with the time \\
$\begin{array}{l}\text { allocated. } \\
\text { 4. The content of REBT Module for support staff can assist staff to think rationally. }\end{array}$ & 84 & .84 \\
$\begin{array}{l}\text { The content of REBT Module for support staff can assist staff in stress } \\
\text { management. }\end{array}$ & 96 & .96 \\
\hline
\end{tabular}

Table 1 shows the overall results obtained from the validity testing of Rational Emotive Behavioural Therapy (REBT) Module based on the statement of each item. The validity testing's results of the module indicated that the content validity coefficient value was .91 . This value was ranging from .84 to .96 for each item.

Most of the experts agreed with the statement that the content of REBT Module can assist the support staff to think rationally and manage their stress which resulting the highest score of validity coefficient of .96 . Then, it was followed by the content validity coefficient of .92 which referring to the module's content can meet the target populations. Meanwhile, the two statements concerning the content of REBT Module can be implemented successfully and compatible with the time allocated, acquired the content validity coefficients of .88 and .84 accordingly.

According to Sidek Mohd Noah dan Jamaludin Ahmad (2005), the determination of good content validity is based on the viewpoint of Tuckman and Waheed (1981) as well as Abu Bakar Nordin (1995) which stated that 70 per cent of the level achievement is considered as higher level of achievement. Thus, it indicates the module has a good content validity if the percentage obtained is above 70 per cent or vice versa.

Generally, all the five experts agreed that the contents of REBT Module is related to the objective in the item 
statements and appropriate to be implemented to the support staff. At the same time, the findings of this study have shown that the content of REBT Module is statistically significant and has a good quality in terms of module's contents because it fulfilled the five criteria of content validity highlighted by Russell (1974). The criteria are the content of the module meet the target population, can be implemented successfully, compatible with time allocated and help the support staff to think rationally and manage their stress.

\subsection{Reliability of Module}

Table 2. Data analysis of reliability testing

\begin{tabular}{lcc}
\hline \multicolumn{1}{c}{ Sub Module REBT } & Number of Activities & Cronbach Alpha \\
\hline Sub module 1: Self- acceptance & 4 & .94 \\
Sub module 2: Feelings & 4 & .96 \\
Sub module 3: Beliefs & 6 & .97 \\
Sub module 4: Disputation & 5 & .95 \\
\hline Reliability Coefficient of the Module & 19 & .98 \\
\hline
\end{tabular}

Table 2 demonstrates the overall results obtained from the reliability testing of Rational Emotive Behavioural Therapy (REBT) Module based on the statement of each item. The reliability analysis was tested by employing a questionnaire based on the steps of module's activity of the module as recommended by Sidek Mohd Noah and Jamaludin Ahmad (2005) during the pilot test. 27 of respondents answered 169 questions based on the 19 activities in the training. Using Statistical Packages for Social Sciences (SPSS) Version 16.0 the finding demonstrated that the value of reliability coefficient is high with .98 .

The results of this testing are also consistent with the fact mentioned by Russell (1974) that the ability of mastering to objective of the module by the subject are determined based on every steps of module's activity. Moreover, the results of this study supported the findings of Mastura Mahfar (2011), Mohd Ali Jaamat (2010), Abdul Hanid Halit (2007), Mariah Kamaruddin (2005), Jamaludin Ahmad (2002) which also shows the acceptable and high coefficient value of reliability in testing their modules.

Further analysis on each sub modules reliability coefficient value presented that sub module 1 (Self-acceptance) was .94, sub module 2 (Feelings) was .96, sub module 3 (Beliefs) was .97 and sub module 4 (Disputation) was .95. Overall findings show that the participants are able to follow all the steps of 19 activities in four sub modules and at the same time understand the objective of the activity. Therefore, this module is acceptable for use in the actual study as according to Sidek Mohd Noah and Jamaludin Ahmad (2005), if the draft module has high reliability and validity, then it could be considered as a module complete and ready for use by researchers in experimental studies.

\section{Implication and Suggestions}

This study may have the potential on development of REBT Module with high validity and reliability by referring to The Sidek's Module Development Model (2001) and a questionnaire based on the steps of activities that suggested by Jamaludin Ahmad (2002). The researcher hopes to contribute the body of knowledge in terms of methodology in developing modules in Malaysia. This study will be able to produce empirical evidences regarding the validity, reliability and usefulness of module. Furthermore, this research could help to provide the organizations and the participants of the program with further and more details information related to REBT approach and assist the university support staff in disputing their irrational beliefs and strengthens their rational beliefs (Ellis, 2006).

Since this REBT Module has high validity and reliability the researchers have a few recommendations for further research in this area. It is suggested that in the future, other researchers can refer to the Sidek's Module Development Model by Sidek Mohd Noah and Jamaludin Ahmad (2005) in order to develop new modules. Meanwhile, to assess the content validity of module, the experts' evaluation can be used and the calculation method of its validity can be referred to Russell's formula (1974). In addition, for the reliability of the module, the questionnaire based on the steps of module's activity of the module as recommended by Jamaludin Ahmad (2002) can be utilised. Lastly, the quantitative and qualitative approach can also be employed in order to confirm the effectiveness of the module development. 


\section{Conclusion}

In conclusion, this research has successfully developed a Rational Emotive Behavioural Therapy (REBT) Module with high value in validity and reliability by following the stages in the Sidek's Module Development Model (Noah \& Ahmad, 2005). Therefore, this module can be executed in the real study and expected to contribute a good effect to the support staff at the university in order to practice the rational beliefs in daily life especially during their work an at the same time provide some contribution to those involved indirectly.

\section{Acknowledgements}

Thank you to the Malaysia Ministry of Higher Education and Universiti Teknologi Malaysia (UTM). This research is being sponsored by MyBrain $15(\mathrm{MyPhD})$.

\section{References}

Ahmad, J. (2002). Kesahan, kebolehpercayaan dan keberkesanan Modul Program Maju Diri ke atas motivasi pencapaian di kalangan pelajar sekolah menengah negeri Selangor (Unpublished doctoral's thesis). Universiti Putra Malaysia. Serdang, Selangor.

Ahsan, N., Abdullah, Z., David Yong, G. F., \& Alam, S. S. (2009). A study of job stress on job satisfaction among staff in Malaysia: empirical study. European Journal of Social Sciences, 8(1), 121-131.

Banks, T., \& Zionts, P. (2009). Teaching a cognitive behavioral strategy to manage emotions: Rational Emotive Behavior Therapy in an educational setting. Intervention in School and Clinic, 44(5), 307-313. http://dx.doi.org/10.1177/1053451208330893

Bernard, M. E., \& Joyce, M. R. (1984). Rational-emotive education and rational-emotive group counseling programs in action Rational-Emotive Therapy with children and adolescents: Theory, Treatment strategies, preventative methods. New York: John Wiley \& Sons, Inc.

Bond, F. W., \& Dryden, W. (1996). Testing an REBT theory: the effects of rational beliefs, irrational beliefs, and their control or certainty contents on the functionality of interference-ii. in a personal context. International Journal of Psychotherapy, 1, 55-77.

Bora, C., Bernard, M. E., Trip, S., Decsei-Radu, A., \& Chereji, S. (2009). Teacher irrational belief scale-preliminary for Romanian population. Journal of Cognitive and Behavioral Psychotherapies, 9(2), 211-220.

Dryden, W. (1998). Developing self-acceptance: A brief, educational, small group approach. New York: John Wiley \& Sons.

Dryden, W. (1999). Rational Emotive Behaviour Therapy : A personal approach. United Kingdom, Winslow Press Limited.

Dryden, W., \& Branch, R. (2008). The fundamentals of Rational Emotive Behaviour Therapy: A training handbook. West Sussex, John Wiley \& Sons, Ltd.

Ellis, A. (1994). Reason and emotion in psychotherapy. New York: Carol Publishing Group.

Ellis, A. (2006). Rational Emotive Behavior Therapy and the mindfulness based stress reduction training of Jon Kabat- Zinn. Journal of Rational-Emotive \& Cognitive-Behavior Therapy, 24(1), 63-78. http://dx.doi.org/10.1007/s10942-006-0024-3

Ellis, A., \& Bernard, M. E. (1983). Rational-emotive approaches to the problems of childhood. New York: Plenum Press.

Ellis, A., \& Dryden, W. (1997). The practice of Rational Emotive Therapy. New York: Springer Publishing Company.

Ellis, A., Gordon, J., Neenan, M., \& Palmer, S. (1997). Stress Counselling: A Rational Emotive Behavior approach. New York: Springer Publishing Company.

Fraenkel, J. R., \& Wallen, N. E. (2006). How to design and evaluate research in education (6th ed.). New York: McGraw-Hill, Inc.

Halit, A. H. (2007). Keberkesanan program kerjaya ke atas perkembangan kerjaya peringkat penerokaan dalam kalangan pelajar sekolah menengah di daerah Dungun, Terengganu, Malaysia (Unpublished doctoral's thesis). Universiti Putra Malaysia. Serdang, Selangor.

Idris, M. A., Dollard, M. F., \& Winefield, A. H. (2010). Lay theory explanations of occupational stress: The 
Malaysian context. Cross Cultural Management: An International Journal, 17(2), 135-153. http://dx.doi.org/10.1108/13527601011038714

Jaamat, M. A. (2010). Mengaplikasi teori Erikson, Piaget dan Super dalam pembinaan Modul Kesedaran Kerjaya untuk pelajar sekolah menengah rendah di Malaysia (Unpublished doctoral's thesis). Universiti Putra Malaysia. Serdang, Selangor.

Jenkins, D., \& Palmer, S. (2003). Counselling in action: a multimodal assessment and Rational Emotive Behavioral approach to stress counselling: A case study. Counselling Psychology Quarterly, 16(3), $265-287$. http://dx.doi.org/10.1080/09515070310001610128

Kamaruddin, M. (2005). Kesahan dan kebolehpercayaan Modul Pembimbing Rakan Sebaya: Kajian di kalangan pelajar tingkatan empat di tiga buah sekolah menengah di daerah Kinta Satu, Perak. Unpublished work. Universiti Putra Malaysia. Serdang, Selangor.

Konting, M. M. (1998). Kaedah Penyelidikan Pendidikan. Kuala Lumpur, Dewan Bahasa dan Pustaka.

Madihie, A., \& Noah, S. M. (2013). An application of the Sidek Module Development in REBT counseling intervention module design for orphans. Procedia - Social and Behavioral Sciences, 84(0), 1481-1491. http://dx.doi.org/10.1016/j.sbspro.2013.06.777

Mahfar, M. (2011). Kesan Modul Pendidikan Rasional Emotif terhadap kepercayaan tidak rasional dan tekanan dalam kalangan pelajar sekolah berasrama penuh di Johor, Malaysia (Unpublished doctoral's thesis). Universiti Putra Malaysia. Serdang, Selangor.

Mahfar, M., Aslan, A. S., Noah, S. M., Ahmad, J., \& Jaafar, W. M. W. (2014). Effects of rational emotive education module on irrational beliefs and stress among fully residential school students in Malaysia. Procedia Social \& Behavioral Sciences, 114, 239-243. http://dx.doi.org/10.1016/j.sbspro.2013.12.692

McMillian, J. H., \& Schumacher, S. (2006). Research in education: Evidence-based inquiry (6th ed.). New York: Pearson Education, Inc.

Mukangi, A. (2010). Rational Emotive Behavioural Therapy (REBT): a critical review. The Journal of Language, Technology \& Entrepreneurship in Africa, 2(1), 54-65. http://dx.doi.org/10.4314/jolte.v2i1.51990

Murphy, L. R., \& Sauter, S. L. (2003). The USA perspective: current issues and trends in the management of work stress. Australian Psychologist, 38(2), 151-157. http://dx.doi.org/10.1080/00050060310001707157

Noah, S. M. (2001). Perkembangan kerjaya: Teori dan praktis. Serdang: Perkhidmatan Percetakan Fakulti Pengajian Pendidikan.

Noah, S. M. (2005). Testing and eveluation in counselling: Theory and application. Serdang, Malaysia: University Putra Malaysia Publisher.

Noah, S. M., \& Ahmad, J. (2005). Pembinaan modul: Bagaimana membina modul latihan dan modul akademik. Serdang: Penerbit Universiti Putra Malaysia.

Nordin, A. B. (1995). Penilaian afektif. Kajang: Masa Enterprise.

Palmer, S. (2002). Cognitive and organisational models of stress that are suitable for use within workplace stress management/ prevention coaching, training and counselling settings. Journal of The Association for Rational Emotive Behaviour Therapy, 10(1), 15-21.

Russell, J. D. (1974). Modular instruction: A guide to the design, selection, utilization and evaluation of modular materials. Minnesota: Burgess Publishing.

Sipon, S. (2007). Keberkesanan kaunseling kelompok pemusatan insan, Rasional Emotif Tingkah Laku dan Psikologi Kognitif Ad-din ke atas tahap tekanan, kepuasan kerja, strategi berdaya tindak dan sokongan sosial guru (Unpublished doctoral's thesis). Universiti Kebangsaan Malaysia. Bangi, Selangor.

Tuckman, B. W., \& Waheed, M. A. (1981). Evaluating an individualized science programme for community college students. Journal of Research in Science Teaching, 18, 489-495. http://dx.doi.org/10.1002/tea.366 0180603

Vernon, A. (1989). Thinking, feeling, behaving: An emotional education curriculum for children. Champaign, Illinois: Research Press.

Vernon, A. (2004). Counselling children and adolescents (3rd ed.). Denver, CO: Love Publishing.

Yin-Fah, B. C., Foon, Y. S., Lim, C.-L., \& Syuhaily, O. (2010). An exploratory study on turnover intention 
among private sector employees. International Journal of Business and Management, 5(8), 57-64.

\section{Copyrights}

Copyright for this article is retained by the author(s), with first publication rights granted to the journal.

This is an open-access article distributed under the terms and conditions of the Creative Commons Attribution license (http://creativecommons.org/licenses/by/3.0/). 